\title{
EFFECT OF ACETYLSALICYLIC ACID ON THE PHYSIOLOGICAL ROLE OF MUCUS GLAND OF LAND SNAIL SPECIES
}

\author{
KANDIL, M. A. ${ }^{1}$, H. I. EL- DEEB ${ }^{2}$, E. A. EWEIS ${ }^{1}$, \\ W.M.GABR ${ }^{2}$ and SOHA A. MOBARAK ${ }^{2}$
}

1. Fac. Agric., Cairo Univ.

2. Plant Protection Research Institute, ARC.Dokki, Giza

(Manuscript received 23 October 2013)

\begin{abstract}
Effect of acetylsalicylic acid, methomyl compound, abamectin bioinsecticide and the joint action of methomyl or abamectin with acetylsalicylic acid were determined on some biochemical parameters (alkaline, acid phosphatase, total protein, lipid and cholesterol) against two land snail species, Eobania vermiculata and Monacha obstructa under laboratory conditions. Snails were tested with $\mathrm{LC}_{50}$ of each tested compound and their mixture using contact technique.

Results showed that the combination of acetylsalicylic acid and methomyl exhibited the highest effect on all biochemical parameters. The $\mathrm{LC}_{50}$ of acetylsalicylic acid caused desiccation and adhesive for snail body of both species. The histopathological effect of $\mathrm{LC}_{50}$ of acetylsalicylic acid on the tissues of mucus gland was studied in both snail species. It was partial as well as complete disappearance, necrosis and atrophy of mucus glandular tissue of E. vermiculata. While it caused focal necrosis especially underneath necroses destructed covering epithelium in association with degeneration in case of $M$. obstructa. Under field conditions, the high efficiency concentrations of tested compounds were tested as a spray. Results revealed that the combination of methomyl and acetylsalicylic acid enhanced the molluscicidal activity against both land snail species in harmony with the result under laboratory condition.

Key words: acetylsalicylic acid- mucus gland- land snails.
\end{abstract}

\section{INTRODUCTION}

During the last few years the terrestrial snails have been injurious pests to a wide varieties of vegetables, fruits, ornamental, flowers and shrubs (Miller et al., 1988). Recently, much effort has been directed toward snail screening and evaluation of chemicals with different pharmacological and physiological modes of action to control land snails especially against their mucus (the first lines of defence). Also, there are very little information available regarding the use of additives, capable of enhancing the action of molluscicides and increase its toxicity. Thereby, the present study was conducted to investigate the molluscicidal activity and biochemical effects of certain pesticides and other compounds. As well as, a trial was carried out to reduce the secretion of mucus by using acetylsalicylic. In addition the potentiation 
effect of acetylsalicylic acid on the toxicity of molluscicides was carried out against two land snail species i.e., the brown garden snail, Eobania vermiculata, and the glassy clover snail, Monacha obstructa,.

The main objective of the current research is to study the following points:

1. The impact of the tested compounds on some biochemical parameters of snails i.e., alkaline and acid phosphatase activity, total protein, total lipid, and cholesterol contents.

2. Pathological and histopathological effects on the two land snail species.

3. To conduct a field trials of tested chemicals against two land snail species.

\section{MATERIALS AND METHODS}

\section{Tested compounds}

a. Methomyl: Newmyl (20\% SL carbamate compound was obtained from KZ Co.

b. Abamectin: Vertimic ( $1.8 \% \mathrm{EC})$ natural product produced by the soil Microorganism, Strptomyces avermitillis. It was obtained from Syngenta Co.

c. Acetylsalicylic acid: Asprin ( $91 \%$ powder). It was supplied by Oxford Co.

\section{Tested animals}

Four- month's old individuals land snails of, Eobania vermiculata and Monacha obstructa were laboratory reared. Animals were adapted to experimental conditions and finally starved for the last $24 \mathrm{~h}$ during adaptation. Ten animals of each species were used for each replicate.

\section{Laboratory Experiments:}

\section{a. Contact (thin layer film) technique:}

Animals were treated with $\mathrm{LC}_{50}$ of each compound i.e. methomyl (0.08 and 0.05 $\left.\mathrm{mg} / \mathrm{cm}^{2}\right)$, abamectin $\left(0.0008\right.$ and $\left.0.0009 \mathrm{mg} / \mathrm{cm}^{2}\right)$ and acetylsalicylic acid $(0.67$ and $0.3 \mathrm{mg} / \mathrm{cm}^{2}$ ) for Eobania vermiculata and Monacha obstructa, respectively as thin layer film according to Kandil et al. (2007).

\section{b. Joint action tests:}

The individual of each snail species were exposed to selected compound mixtures ( $\mathrm{LC}_{25}$ of each) using contact technique applications (Kandil et. al. 2007).

\section{c. Biochemical studies:}

Animals were treated with $\mathrm{LC}_{50}$ of each compound and their mixture to determine their effect on some biochemical parameters i.e. alkaline and acid phosphatase activity, total protein, total lipid and cholesterol contents. These parameters were measured at 1,3 , and 7 days post treatment. A parallel control test was conducted. 
- Sample Preparation: Ten animals of each species at $1 \mathrm{~g}$ weight were used according to method of Bergmeyer (1963).

a. Determination of alkaline phosphatase (ALP) and acid phoshatase (ACP) activity: The method of determination of alkaline and acid phosphatase was described by Kind and King (1954). ALP was determined using phenyl phosphate, while ACP was determined using sodium phenyl phosphate as a substrate.

b. Determination of total protein: Colorimetric method of soluble protein was done According to the method of Henry (1964) using Buiret reagent.

c. Determination of total lipid: Lipids are hydrolysed by sulphoric acid, then treated with phosphovanilin mixture to produce sulphophosphovanilin complex of rose coloration which is measured photometrically according to Zollner and Kirsch (1962).

e. Determination of cholesterol: The colorimetric determination of cholesterol concentration was carried out according to the method of Ellefson and Caraway (1976).

d. Histopathological studies: The histopathological effects of the acetylsalicylic acid on the mucus gland of the foot was observed and recorded for both snail species. The method was done according to Banchroft et. al. (1996).

\section{Field Experiments:}

Methomyl compound, abamectin bioinsecticide, acetylsalicylic acid and mixture of the last compound with each two pesticides were tested against two land species under field conditions. The effecancy of each compound was based on the reduction of snail population after 7 days of treatment according to the formula of Henderson and Tilton (1952).

\section{RESULTS AND DISCUSSION}

\section{Biochemical impacts of two pesticides and acetylsalicylic acid on Eobania} vermiculata and Monacha obstructa:

\section{a. Alkaline and acid phosphatase:}

Data in Table (1) illustrate the effect of abamectin, methomyl and their combination with acetylsalicylic acid on alkaline phosphatase in both land snail species after different periods. Results revealed that methomyl treatment reduced the enzyme level gradually to $404.7,338.7$ and $225.4 \mathrm{U} / \mathrm{L}$ after 1,3 and 7 days, respectively comparing with $768.3 \mathrm{U} / \mathrm{L}$ in control for $E$. vermiculata. Similar result was observed by abamectin as it inhibited alkaline phosphatase from $768.3 \mathrm{U} / \mathrm{L}$ for control to $418.4,295.4 \mathrm{U} / \mathrm{l}$ post 1,3 day of treatment, then increased to $373.3 \mathrm{U} / \mathrm{L}$ at the $7^{\text {th }}$ 
day but it was lower than the normal activity of control. Concerning acetylsalicylic acid, emphasize reduced happened in the enzyme activity to $33.47 \mathrm{U} / \mathrm{L}$ after 1 day while it raised to 65.7 and $255.7 \mathrm{U} / \mathrm{L}$ after 3 and 7 days but these values considered less than control activity (768.3 U/L). The combination of methomyl + acetylsalicylic acid inhibited the enzyme activity from $768.3 \mathrm{U} / \mathrm{L}$ for control to $260.5 \mathrm{U} / \mathrm{L}$ after one day while it was completely absent post three days after treatment. The combination between abamectin bioinsecticide and acetylsalicylic acid reduced the enzyme activity to $278.1 \mathrm{U} / \mathrm{L}$ after one day of treatment, then increased up to 309.9 and $485.0 \mathrm{U} / \mathrm{L}$ in the third and seventh days, respectively comparatively with $768.3 \mathrm{U} / \mathrm{L}$ for control. Regarding Monacha obstructa, similar results were obtained for the most tested compounds. After one day, methomyl reduced the enzyme concentration from 437.5 $\mathrm{U} / \mathrm{L}$ for control to $110.0 \mathrm{U} / \mathrm{L}$, then it increased this value up to 320 post three days and decreased again to $105.4 \mathrm{U} / \mathrm{L}$ in the $7^{\text {th }}$ day. Gradually inhibition occurred in the enzyme activity to $385.8,228.4$ and $102.3 \mathrm{U} / \mathrm{L}$ after 1,3 and 7 days consecutively in case of abamectin treatment comparing with 437.5 of control. Also, acetylsalicylic acid decreased alkaline phosphatase activity to 198.4 and $157.8 \mathrm{U} / \mathrm{L}$ in the first and third day of treatment, respectively while increased to reach $264.2 \mathrm{U} / \mathrm{L}$ after 7 days but still less than normal activity (437.5 $\mathrm{U} / \mathrm{L}$ for control). Adverse way occurred for the combination of methomyl and acetylsalicylic acid as it induced slightly increase for the enzyme activity from $437.5 \mathrm{U} / \mathrm{L}$ of control to reach $455.4 \mathrm{U} / \mathrm{L}$ after one day of treatment while the enzyme was completely absent in the third day. The combination of abamectin + acetylsalicylic acid reduced the enzyme activity gradually from 437.5 $\mathrm{U} / \mathrm{L}$ for control to $407.7,175.5$ and $145.7 \mathrm{U} / \mathrm{L}$ after 1,3 and 7 day, consecutively. The above data revealed that the combination of methomyl and acetylsalicylic acid was the most effective on alkaline phosphatase activity in both species of land snail. The present results are in accordance with those obtained by Rao et al. (2003) they observed significantly altered in the activity of alkaline phosphatase in the nervous tissue of snail that treated by single and binary treatments of plant derived molluscicides.

Data in Table (2) showed the effect of the same tested compounds when used as a contact on acid phosphatase enzyme in the two tested snail species. Results indicate that methomyl compound had the same effect on the enzyme in both snail species. It reduced the enzyme activity to $0.076,0.410$ and $1.050 \mathrm{U} / \mathrm{L}$ for $E$. vermiculata and $0.410,0.406$ and $2.147 \mathrm{U} / \mathrm{L}$ in case of $M$. obstructa after 1,3 and 7 days, respectively comparing with 3.377 and $3.290 \mathrm{U} / \mathrm{L}$ in control for the two species, respectively. Also, abamectin bioinsecticide took the same pattern whereas the enzyme activity reduced to $0.120 \& 0.066$ after one day, $0.170 \& 0.180$ post 3 day and 
$0.220 \& 0.476 \mathrm{U} / \mathrm{L}$ after 7 day for $E$. vermivulata and M. obstructa, respectively. Acetylsalicylic acid differed in its effect on the enzyme in both snail species whereas it reduced the enzyme activity to $2.947 \mathrm{U} / \mathrm{L}$ in the $1^{\text {st }}$ day and start in increasing to reach $5.757 \mathrm{U} / \mathrm{L}$ at the $7^{\text {th }}$ day over than control activity (3.377U/L) for E. vermiculata. But it had weak effect in case of M. obstructa as the enzyme activity was nearly to control activity in the three tested periods i.e. 3.283, 3.460 and $3.953 \mathrm{U} / \mathrm{L}$ after 1,3 and 7 days of treatment. Acetylsalicylic acid when added to methomyl gave sever effect on the enzyme in both snail species. After one day of treatment the enzyme activity increased from 3.377 of control up to $4.557 \mathrm{U} / \mathrm{L}$ in case of $E$. vermiculata while it decreased from 3.290 to $2.260 \mathrm{U} / \mathrm{L}$ for $M$ obstructa, then it was completely hidden after 3 days in both snail species. Also, acute effect on the enzyme activity was observed in case of the combination of acetylsalicylic acid plus abamectin. The enzyme activity reduced from 3.377 to $0.800,0.450$ and $1.360 \mathrm{U} / \mathrm{L}$ for $E$. vermiculata while it decreased from 3.290 to $1.133,0.636$ and $0.776 \mathrm{U} / \mathrm{L}$ in case of $M$. obstructa at the three tested periods, consecutively.

Reviewing the aforementioned results in Table $(1,2)$ we can observed that acetylsalicylic acid when combined with methomyl was more effective against both alkaline and acid phosphatase enzymes than each compound alone in the two snail species. Beltagi et al, (2011) found that Thymol and Nicotine caused a marked enhancement in the activity of acid phosphatase (ACP) in the haemolymph of Eobania vermiculata while the activity of alkaline phosphatase (ALP) exhibited a significant suppression.

\section{d. Total protein:}

The response of total protein to the different treatment as a contact against both snail species was shown in Table (3). Data showed gradually significant increase induced in total protein in the all tested compounds against both snail species in the three tested periods except the combination of methomyl + acetylsalicylic acid. The total protein level increased gradually from $0.173 \mathrm{~g} / \mathrm{dL}$ to reach up to $2.367,2.837$, 2.240 and $2.367 \mathrm{~g} / \mathrm{dL}$ after 7 days of treatment with methomyl, abamectin, acetylsalicylic acid and combination of abamectin + acetylsalicylic acid, respectively for $E$. vermiculata. Also, the same compounds increased total protein gradually from o. $160 \mathrm{~g} / \mathrm{dL}$ to $0.733,2.713,3.243$ and $2.230 \mathrm{~g} / \mathrm{dl}$, consecutively after 7 days in case of $M$. obstructa. The mixture of methomyl with acetylsalicylic acid had decline effect whereas it increased the total protein from 0.173 to $0.773 \mathrm{~g} / \mathrm{dL}$ for E. vermiculata and from 0.160 up to $1.043 \mathrm{~g} / \mathrm{dL}$ for $M$. obstructa after one day of treatment, then the total protein was hidden in the $3^{\text {rd }}$ and $7^{\text {th }}$ days and its value was 0.0 . The previous results proved that acetylsalicylic acid when combined with methomyl had the highest effect 
on total protein than the other compounds when used as a bait or contact against both snail species. The fluctuation in the level of total protein might be resulted from imbalance between the rate of synthesis and rate of degradation. Khater et al. (1990) reported that the increase in total protein could be attributed to the increased biosynthesis process occurred by high enzyme stress.

\section{c. Total Lipid:}

The effect of the tested compounds on total lipid was different when used as a contact against both snail species as shown in Table (4). Acetylsalicylic acid alone decreased the level of total lipid from 7.033 to $2.477 \mathrm{~g} / \mathrm{dL}$ after the first day of treatment, then it increased up to 4.737 in the third day and reached to over than control level after 7 days $(9.33 \mathrm{~g} / \mathrm{dL})$ for E. vermiculata. The same compound enhanced the total lipid gradually up to $6.183,6.887$ and $9.403 \mathrm{~g} / \mathrm{dL}$ after 1,3 and 7 days comparatively with $4.810 \mathrm{~g} / \mathrm{dL}$ for control in case of $M$. obstructa. The same acid when added to methomyl differed in its effect whereas it reduced total lipid from 7.033 to $2.127 \mathrm{~g} / \mathrm{dL}$ for E. vermiculata and from 4.810 to $2.557 \mathrm{~g} / \mathrm{dL}$ for M. obstructa then total lipid was completely absent for both species after 3 and 7 days. The rest compounds i.e. methomyl, abamectin and combination of abamectin with acetylsalicylic acid had similar effect whereas they reduced total lipid in the first day of administration and fluctuated in their effect in the third day but all these compounds reduced total lipid after 7 days in both species. The reducing in total lipid in the $7^{\text {th }}$ day reached to $1.567,2.167$ and $1.503 \mathrm{~g} / \mathrm{dL}$ for methomyl, abamectin and the combination of abamectin + acetylsalicylic acid, respectively comparing with 7.033 $\mathrm{g} / \mathrm{dL}$ for control of $E$. vermiculata. While these values were $1.52,3.09$ and $3.32 \mathrm{~g} / \mathrm{dL}$ for the same compounds, respectively after 7 days comparing with $4.810 \mathrm{~g} / \mathrm{dL}$ of control in case of M. obstructa. The fluctuation in total lipid level may be attribute to the imbalance between the rate of synthesis and degradation process. Also, the depression in total lipid may be due to decline in lipid synthesis capacity and / or attribute to an increase in the hydrolysis of hepatic lipid to compact the stress conditions as reported by Saxena et al. (1989).

\section{d. Cholesterol:}

The data compiled in Table (5) illustrate the response of cholesterol in both snail species to the previous tested compounds when used as a contact. Results cleared that methomyl, abamectin and combination of abamectin with acetylsalicylic acid achieved the same effect on the cholesterol against $E$. vermiculata as the three compounds reduced cholesterol level in the first and third days to (211.5 and 204.4), (206.5 and 201.5) and (210.7 and $205.5 \mathrm{mg} / \mathrm{dL}$ ) for the three compounds, respectively. While the same compounds increased these level in the $7^{\text {th }}$ up to 207.1 , 
204.3 and $207.5 \mathrm{mg} / \mathrm{dL}$, consecutively but it was less than control level ( 251.7 $\mathrm{mg} / \mathrm{dL}$ ). The response of cholesterol was differed in case of acetylsalicylic acid as its level enhanced gradually in the three tested periods to reached up to $475.2 \mathrm{mg} / \mathrm{dL}$ (over than control level $251.7 \mathrm{mg} / \mathrm{dL}$ ) after 7 days of administration. In contrast, acetylsalicylic acid when combined with methomyl decreased the level of cholesterol to $234.4 \mathrm{mg} / \mathrm{dL}$ after one day to reach 0.0 after 3 days. Concerning M. obstructa, the response of cholesterol took one way with methomyl and the mixture of abamectin + acetylsalicylic acid whereas it reduced to $201.5,199.5$ and $192.7 \mathrm{mg} / \mathrm{dL}$ for the first compound and 207.2, 205.7 and $204.7 \mathrm{mg} / \mathrm{dL}$ for the second after 1,3 and 7 days of treatment comparing with $477.9 \mathrm{mg} / \mathrm{dL}$ for control. Strong effect occurred by abamectin bioinsecticide as it reduced cholesterol level from $477.9 \mathrm{mg} / \mathrm{dL}$ for control to reach $0.476 \mathrm{mg} / \mathrm{dL}$ in the $7^{\text {th }}$ day of treatment. Also, the combination of methomyl with acetylsalicylic acid was more severity where it reduced cholesterol to 0.0 after 3 days of treatment. Beltagi et al (2011) detected that Thymol and Nicotine were increased the level of total protein, total lipid and cholesterol in the haemolemph of Eobania vermiculata snail

Discussing the previous results in Table (1-5) it is obvious that acetylsalicylic acid exhibited good and satisfactory results when used alone on the all tested biochemical parameters while its effect was more strong when added to the tested compounds especially with methomyl as enhanced its toxicity drastically in the all treatments. Acetylsalicylic acid had strong effect on ALP and ACP enzymes which are responsible to the mucus secretion of snail this effect lead to inhibit the production of the mucus and shell materials that is very important for snail life. Also, acetylsalicylic acid affect on total protein (one of the important contents of mucus). The same acid affected on the total lipid and cholesterol which important for synthesis of shell. At therapeutically, Mitobe et al. (2000) reported that the enhancement of the risk factor ROS (reactive oxygen species) induced injury by acetylsalicylic acid may be accomplished through diminished gastric mucus synthesis, since mucus is a potent scavenger of ROS.

\section{Pathological syndrome of acetylsalicylic acid}

\section{a. Pathological symptoms}

Figs. (1- 4) showed the pathological symptoms caused by $\mathrm{LC}_{50}$ of acetylsalicylic acid on both snail species comparing with the control. Figs. $(2,4)$ showed that the death of treated animals for both snail species are accompanied with dry and adhesive with the dish surface comparing with untreated animals of both species in Figs. $(1,3)$. These observations may be due to reduce in the mucus secretion 
that caused by acetylsalicylic acid and led to death. Wang et al (2007) suggested that aspirin treated inhibit the mucus secretion and mucosal blood flow may be involved.

\section{b. Histopathological effects:}

The histopathological findings of the mucous glands of $E$. vermiculata and $M$. obstructa treated with $\mathrm{LC}_{50}$ of acetylsalicylic acid are shown in Fig. (5-10). Regarding E. vermiculata, Fig. (5) showed that there was no histopathological alteration observed and normal histological structure of the pseudostratified columner covering epithelial layer with the underlying basophilic mucous glands which was embedded in the muscular layer as well as the other side which had finger like projection of the folds all of them were recorded in untreated animals (control). In the treated snails, Fig. $(6,7)$ exhibited that there was partial as well as complete disappearance and necrosis of the basophilic mucous glandular tissue associated with atrophy and necrosis of the covering epithelia layer and the muscular layer as the finger-like projection of the folds comparatively with the untreated animals of control. Concerning M. obstructa, Fig. (8) noticed that the basophilic mucous glands were histological present underneath the covering pseudostratified columner epithelium in heavy and condensed manner as well as in the deep muscular layer associated with the appearance of normal folds in the other side of the untreated snails. Fig. $(9,10)$ showed the histopathological changes in the treated animals of M. obstructa. It is recorded that the mucous glandular structure showed focal necrosis specially underneath necrosis destructed covering epithelium in association with degeneration, necrosis and dispersion in the musculature. From the obtained findings, it is cleared that acetylsalicylic acid caused intense effect on the mucous gland tissues of both snail species. These effects lead to inhibition of mucous synthesis which is very important for snail life. These results are in agreement with Abdl- Kader Samah (2001) she suggested that the death of snails is shown to be primarily correlated with the complete destruction of the foot tissues and the consequent great loss of the total body water content.

\section{Field experiments:}

The field performance of the tested compounds against $E$. vermiculata was shown in Table (6). Results revealed that the combination of methomyl with acetylsalicylic acid achieved the highest population reduction percentage of snails (91.7\%) followed by acetylsalicylic acid alone (86.0\%), mixture of abamectin + acetylsalicylic acid (85.0\%) and methomyl (70.5\%) while abamectin bioinsecticide was the lowest effective one as it gave only $62.0 \%$ reduction of snail population. 
Data shown in Table (7) present the comparative efficiency of the same tested compounds against Monacha obstructa under field conditions. Results indicate that the combination between methomyl and acetylsalicylic acid was still the most effective one with highest values of population reduction (88.2\%) while methomyl alone jumped from the fourth position to the second rank whereas it caused $84.8 \%$. The mixtures of abamectin plus acetylsalicylic acid keep in the third position with 60.6 $\%$ population reduction. Abamectin alone elevated to the fourth position (51.3\%) while acetylsalicylic acid came in the last rank as the lowest effective compound whereas it failed to achieve good result where it gave only $35.4 \%$ population reduction.

Comparing the data in Tables $(6,7)$ it is cleared that under field conditions $E$. vermiculata was more susceptible than $M$. obstructa to the combination of methomyl + acetylsalicylic acid (the first effective compound whereas it caused $91.7 \%$ population reduction for the first species comparatively with $88.2 \%$ in case of the second. The field results are in contrast with those were obtained by laboratory trails. However abamectin bioinsecticide was the superior compound in the laboratory it was the lowest effective under field conditions. This observation may be due to the weather factors or natural conditions (temperature, humidity, light......etc.). These factors may affect this compound inducing degradation or decomposition led to reduce its toxic action against snails. As well known abamectin is rapidly degraded in soil surface, with half- lives 8 hours to 1 day (Price, 1984). The differences in the susceptibility level may be attributed to the physiological state of the snail which changes from species to another. Similar results were obtained by Gabr et al. (2006 ab). 
Table 1. Effect of $\mathbf{L C}_{50}$ of methomyl, abamectin and their combination with acetylsalicylic acid ( $\mathrm{LC}_{25}$ of each) as contact on alkaline phosphatase activity $(\mathrm{U} / \mathrm{L})$ in two land snail species.

\begin{tabular}{|c|c|c|c|c|c|c|c|}
\hline \multirow{2}{*}{$\begin{array}{c}\text { Snail } \\
\text { species }\end{array}$} & \multirow{2}{*}{$\begin{array}{l}\text { Periods } \\
\text { after } \\
\text { treatment }\end{array}$} & \multicolumn{5}{|c|}{ Alkaline phosphatase (ALP) activity (U/L) } & \multirow[b]{2}{*}{ LSD } \\
\hline & & $\begin{array}{c}\text { Methomyl } \\
\text { (M) }\end{array}$ & $\begin{array}{c}\text { Abmectin } \\
(\mathrm{Ab})\end{array}$ & A-Acid & $M+A$ & $A b+A$ & \\
\hline \multirow{4}{*}{$\begin{array}{c}\text { Eobania } \\
\text { vermiculata }\end{array}$} & Control & $\begin{array}{c}768.3 \\
\pm 0.9 \\
\end{array}$ & $\begin{array}{c}768.3 \\
\pm 0.9 \\
\end{array}$ & $\begin{array}{c}768.3 \pm \\
0.9 \\
\end{array}$ & $\begin{array}{c}768.3 \pm \\
0.9 \\
\end{array}$ & $\begin{array}{c}768.3 \\
\pm 0.9 \\
\end{array}$ & 0.018 \\
\hline & 1day & $\begin{array}{l}404.7 \\
\pm 0.3 \\
\end{array}$ & $\begin{array}{c}418.4 \\
\pm 0.1 \\
\end{array}$ & $\begin{array}{r}33.47 \\
\pm 0.1 \\
\end{array}$ & $\begin{array}{c}260.5 \\
\pm 0.1 \\
\end{array}$ & $\begin{array}{c}278.1 \\
\pm 0.1 \\
\end{array}$ & 11.89 \\
\hline & 3days & $\begin{array}{l}338.7 \\
\pm 0.0 \\
\end{array}$ & $\begin{array}{c}295.4 \\
\pm 0.4 \\
\end{array}$ & $\begin{array}{c}65.70 \\
\pm 0.3 \\
\end{array}$ & $\begin{array}{c}0.000 \\
\pm 0.0 \\
\end{array}$ & $\begin{array}{c}309.9 \\
\pm 0.6\end{array}$ & 7.921 \\
\hline & 7days & $\begin{array}{c}225.4 \\
\pm 0.2\end{array}$ & $\begin{array}{c}373.3 \\
\pm 0.1\end{array}$ & $\begin{array}{r}255.7 \\
\pm 0.3\end{array}$ & $\begin{array}{c}0.000 \\
\pm 0.0 \\
\end{array}$ & $\begin{array}{c}485.0 \\
\pm 0.1\end{array}$ & 11.47 \\
\hline \multicolumn{2}{|c|}{ LSD } & 99.81 & 97.41 & 116.9 & 95.40 & 99.63 & \\
\hline \multirow{4}{*}{$\begin{array}{l}\text { Monacha } \\
\text { obstructa }\end{array}$} & Control & $\begin{array}{c}437.5 \pm \\
1.9\end{array}$ & $\begin{array}{c}437.5 \\
\pm 1.9 \\
\end{array}$ & $\begin{array}{c}437.5 \pm \\
1.9 \\
\end{array}$ & $\begin{array}{c}437.5 \\
\pm 1.9 \\
\end{array}$ & $\begin{array}{c}437.5 \\
\pm 2.9 \\
\end{array}$ & 0.381 \\
\hline & 1day & $\begin{array}{l}110.0 \\
\pm 2.4 \\
\end{array}$ & $\begin{array}{c}385.8 \\
\pm 1.6 \\
\end{array}$ & $\begin{array}{c}198.4 \\
\pm 1.3 \\
\end{array}$ & $\begin{array}{l}455.4 \\
\pm 2.3 \\
\end{array}$ & $\begin{array}{l}407.7 \\
\pm 2.3 \\
\end{array}$ & 3.945 \\
\hline & 3days & $\begin{array}{l}320.5 \\
\pm 2.2 \\
\end{array}$ & $\begin{array}{c}228.4 \\
\pm 1.0 \\
\end{array}$ & $\begin{array}{c}157.8 \\
\pm 2.2 \\
\end{array}$ & $\begin{array}{l}0.000 \\
\pm 0.0 \\
\end{array}$ & $\begin{array}{l}175.5 \\
\pm 2.5 \\
\end{array}$ & 5.191 \\
\hline & 7days & $\begin{array}{c}105.4 \\
\pm 3.3 \\
\end{array}$ & $\begin{array}{c}102.3 \\
\pm 1.4 \\
\end{array}$ & $\begin{array}{c}264.2 \\
\pm 2.7 \\
\end{array}$ & $\begin{array}{c}0.000 \\
\pm 0.0 \\
\end{array}$ & $\begin{array}{l}145.7 \\
\pm 2.6 \\
\end{array}$ & 4.711 \\
\hline \multicolumn{2}{|c|}{ LSD } & 5.797 & 2.811 & 4.409 & 2.761 & 5.504 & \\
\hline
\end{tabular}

A $=$ acetylsalicylic acid

$M=$ methomyl

$A b=$ abamectin 
Table 2. Effect of $\mathbf{L C}_{50}$ of methomyl, abamectin and their combination with acetylsalicilic acid ( $\mathrm{LC}_{25}$ of each) as contact on acid phosphatase activity $(\mathrm{U} / \mathrm{L})$ in two land snail species

\begin{tabular}{|c|c|c|c|c|c|c|c|}
\hline \multirow{2}{*}{$\begin{array}{c}\text { Snail } \\
\text { species }\end{array}$} & \multirow{2}{*}{$\begin{array}{c}\text { Periods } \\
\text { after } \\
\text { treatment }\end{array}$} & \multicolumn{5}{|c|}{ Acid phosphatase (ACP) activity (U/L) } & \multirow[b]{2}{*}{ LSD } \\
\hline & & $\begin{array}{c}\text { Methomyl } \\
\text { (M) }\end{array}$ & $\begin{array}{c}\text { Abmectin } \\
(A b)\end{array}$ & A-Acid & $\mathrm{M}+\mathrm{A}$ & $A b+A$ & \\
\hline \multirow{4}{*}{$\begin{array}{c}\text { Eobania } \\
\text { vermiculata }\end{array}$} & Control & $\begin{array}{r}3.377 \\
\pm 0.1\end{array}$ & $\begin{array}{l}3.377 \\
\pm 0.1\end{array}$ & $\begin{array}{l}3.377 \\
\pm 0.1\end{array}$ & $\begin{array}{r}3.377 \\
\pm 0.1\end{array}$ & $\begin{array}{r}3.377 \\
\pm 0.1\end{array}$ & 0.018 \\
\hline & 1day & $\begin{array}{l}0.076 \\
\pm 0.0 \\
\end{array}$ & $\begin{array}{c}0.120 \\
\pm 0.0 \\
\end{array}$ & $\begin{array}{l}2.947 \\
\pm 0.1 \\
\end{array}$ & $\begin{array}{l}4.557 \\
\pm 0.1 \\
\end{array}$ & $\begin{array}{l}0.800 \\
\pm 0.0 \\
\end{array}$ & 0.119 \\
\hline & 3days & $\begin{array}{l}0.410 \\
\pm 0.0\end{array}$ & $\begin{array}{l}0.170 \\
\pm 0.0\end{array}$ & $\begin{array}{c}3.623 \\
\pm 0.0\end{array}$ & $\begin{array}{l}0.000 \\
\pm 0.0\end{array}$ & $\begin{array}{l}0.450 \\
\pm 0.1\end{array}$ & 0.059 \\
\hline & 7days & $\begin{array}{r}1.050 \\
\pm 0.0 \\
\end{array}$ & $\begin{array}{c}0.220 \\
\pm 0.0\end{array}$ & $\begin{array}{l}5.757 \\
\pm 0.0 \\
\end{array}$ & $\begin{array}{l}0.000 \\
\pm 0.0 \\
\end{array}$ & $\begin{array}{c}1.360 \\
\pm 0.1 \\
\end{array}$ & 0.059 \\
\hline \multicolumn{2}{|c|}{ LSD } & 0.0631 & 0.0631 & 0.1672 & 0.063 & 0.126 & \\
\hline \multirow{4}{*}{$\begin{array}{l}\text { Monacha } \\
\text { obstructa }\end{array}$} & Control & $\begin{array}{r}3.290 \\
\pm 0.1 \\
\end{array}$ & $\begin{array}{r}3.290 \\
\pm 0.1 \\
\end{array}$ & $\begin{array}{c}3.290 \\
\pm 0\end{array}$ & $\begin{array}{r}3.290 \\
\pm 0.1 \\
\end{array}$ & $\begin{array}{c}3.290 \\
\pm 0.1 \\
\end{array}$ & 0.018 \\
\hline & 1day & $\begin{array}{l}0.410 \\
\pm 0.0\end{array}$ & $\begin{array}{c}0.066 \\
\pm 0.0\end{array}$ & $\begin{array}{c}3.283 \\
\pm 0.1\end{array}$ & $\begin{array}{c}2.260 \\
\pm 0.1\end{array}$ & $\begin{array}{c}1.133 \\
\pm 0.1\end{array}$ & 0.168 \\
\hline & 3days & $\begin{array}{r}0.406 \\
\pm 0.0 \\
\end{array}$ & $\begin{array}{c}0.180 \\
\pm 0.0 \\
\end{array}$ & $\begin{array}{c}3.460 \\
\pm 0.1 \\
\end{array}$ & $\begin{array}{l}0.000 \\
\pm 0.0 \\
\end{array}$ & $\begin{array}{c}0.636 \\
\pm 0.1 \\
\end{array}$ & 0.059 \\
\hline & 7days & $\begin{array}{r}2.147 \\
\pm 0.7 \\
\end{array}$ & $\begin{array}{c}0.476 \\
\pm 0.0\end{array}$ & $\begin{array}{c}3.953 \\
\pm 0.1 \\
\end{array}$ & $\begin{array}{l}0.000 \\
\pm 0.0 \\
\end{array}$ & $\begin{array}{c}0.776 \\
\pm 0.1 \\
\end{array}$ & 0.084 \\
\hline \multicolumn{2}{|c|}{ LSD } & 2.754 & 0.063 & 0.167 & 0.141 & 0.063 & \\
\hline
\end{tabular}

$A=$ acetylsalicylic acid

$M=$ methomyl

$\mathrm{Ab}=$ abamectin 
Table 3. Effect of $L_{50}$ of methomyl, abamectin and their combination with acetylsalicylic acid ( $\mathrm{LC}_{25}$ of each) as contact on total protein $(\mathrm{g} / \mathrm{dL})$ in two land snail species

\begin{tabular}{|c|c|c|c|c|c|c|c|}
\hline \multirow{2}{*}{$\begin{array}{l}\text { Snails } \\
\text { species }\end{array}$} & \multirow{2}{*}{$\begin{array}{c}\text { Periods } \\
\text { after } \\
\text { treatment }\end{array}$} & \multicolumn{5}{|c|}{ Total protein $(\mathrm{g} / \mathrm{dL})$} & \multirow[b]{2}{*}{ LSD } \\
\hline & & $\begin{array}{c}\text { Methomyl } \\
\text { (M) }\end{array}$ & $\begin{array}{c}\text { Abmectin } \\
(\mathrm{Ab})\end{array}$ & A-Acid & $M+A$ & $A b+A$ & \\
\hline \multirow{4}{*}{$\begin{array}{c}\text { Eobania } \\
\text { vermiculata }\end{array}$} & Control & $\begin{array}{c}0.173 \pm \\
0.1 \\
\end{array}$ & $\begin{array}{c}0.173 \pm \\
0.1 \\
\end{array}$ & $\begin{array}{c}0.173 \pm \\
0.1 \\
\end{array}$ & $\begin{array}{c}0.173 \pm \\
0.1 \\
\end{array}$ & $\begin{array}{c}0.173 \pm \\
0.1 \\
\end{array}$ & 0.018 \\
\hline & 1day & $\begin{array}{c}2.663 \pm \\
0.2\end{array}$ & $\begin{array}{c}0.470 \pm \\
0.1\end{array}$ & $\begin{array}{c}1.560 \pm \\
0.1\end{array}$ & $\begin{array}{c}0.773 \pm \\
0.1\end{array}$ & $\begin{array}{c}2.663 \pm \\
0.2\end{array}$ & 0.245 \\
\hline & 3days & $\begin{array}{c}1.610 \pm \\
0.1 \\
\end{array}$ & $\begin{array}{c}1.127 \pm \\
0.1 \\
\end{array}$ & $\begin{array}{c}1.960 \pm \\
0.1 \\
\end{array}$ & $\begin{array}{c}0.000 \pm \\
0.0\end{array}$ & $\begin{array}{c}1.610 \pm \\
0.2 \\
\end{array}$ & 0.157 \\
\hline & 7days & $\begin{array}{c}2.367 \pm \\
0.1 \\
\end{array}$ & $\begin{array}{c}2.837 \pm \\
0.1 \\
\end{array}$ & $\begin{array}{c}2.240 \pm \\
0.1 \\
\end{array}$ & $\begin{array}{c}0.000 \pm \\
0.0 \\
\end{array}$ & $\begin{array}{c}2.367 \pm \\
0.2 \\
\end{array}$ & 0.157 \\
\hline \multicolumn{2}{|c|}{ LSD } & 0.3159 & 0.1264 & 0.1413 & 0.1264 & 0.3159 & \\
\hline \multirow{4}{*}{$\begin{array}{l}\text { Monacha } \\
\text { obstructa }\end{array}$} & Control & $0.160 \pm 0.1$ & $\begin{array}{c}0.160 \pm \\
0.1\end{array}$ & $\begin{array}{c}0.160 \pm \\
0.1\end{array}$ & $\begin{array}{c}0.160 \pm \\
0.1\end{array}$ & $\begin{array}{c}0.160 \pm \\
0.1\end{array}$ & 0.018 \\
\hline & 1day & $\begin{array}{c}0.686 \pm \\
0.1 \\
\end{array}$ & $\begin{array}{c}0.150 \pm \\
0.3\end{array}$ & $\begin{array}{c}1.230 \pm \\
0.1\end{array}$ & $\begin{array}{c}1.043 \pm \\
0.1\end{array}$ & $\begin{array}{c}2.377 \pm \\
0.1 \\
\end{array}$ & 0.157 \\
\hline & 3days & $\begin{array}{c}0.930 \pm \\
0.1 \\
\end{array}$ & $\begin{array}{c}1.173 \pm \\
0.1 \\
\end{array}$ & $\begin{array}{c}2.267 \pm \\
0.1 \\
\end{array}$ & $\begin{array}{c}0.000 \pm \\
0.0\end{array}$ & $\begin{array}{c}0.676 \pm \\
0.1 \\
\end{array}$ & 0.222 \\
\hline & 7days & $\begin{array}{c}0.733 \pm \\
0.0\end{array}$ & $\begin{array}{c}2.713 \pm \\
0.1\end{array}$ & $\begin{array}{c}3.243 \pm \\
0.1\end{array}$ & $\begin{array}{c}0.000 \pm \\
0.0\end{array}$ & $\begin{array}{c}2.230 \pm \\
0.0\end{array}$ & 0.133 \\
\hline \multicolumn{2}{|c|}{ LSD } & 0.1672 & 0.1998 & 0.2364 & 0.1094 & 0.2447 & \\
\hline
\end{tabular}

A= acetylsalicylic acid

$M=$ methomyl

$\mathrm{Ab}=$ abamectin 
Table 4. Effect of $\mathrm{LC}_{50}$ of methomyl, abamectin and their combination with acetylsalicylic acid ( $\mathrm{LC}_{25}$ of each) as contact on total lipid $(\mathrm{g} / \mathrm{L})$ in two land snail species

\begin{tabular}{|c|c|c|c|c|c|c|c|}
\hline \multirow{2}{*}{$\begin{array}{c}\text { Snail } \\
\text { species }\end{array}$} & \multirow{2}{*}{$\begin{array}{c}\text { Periods } \\
\text { after } \\
\text { treatment }\end{array}$} & \multicolumn{5}{|c|}{ Total lipid $(\mathrm{g} / \mathrm{L})$} & \multirow[b]{2}{*}{ LSD } \\
\hline & & $\begin{array}{c}\text { Methomyl } \\
\text { (M) }\end{array}$ & $\begin{array}{c}\text { Abmectin } \\
\text { (Ab) }\end{array}$ & A-Acid & $M+A$ & $A b+A$ & \\
\hline \multirow{4}{*}{$\begin{array}{c}\text { Eobania } \\
\text { vermiculata }\end{array}$} & Control & $\begin{array}{c}7.033 \\
\pm 0.3 \\
\end{array}$ & $\begin{array}{r}7.033 \\
\pm 0.3 \\
\end{array}$ & $\begin{array}{c}7.033 \\
\pm 0.3 \\
\end{array}$ & $\begin{array}{r}7.033 \\
\pm 0.3 \\
\end{array}$ & $\begin{array}{r}7.033 \\
\pm 0.3 \\
\end{array}$ & 0.018 \\
\hline & 1day & $\begin{array}{c}2.563 \\
\pm 0.1 \\
\end{array}$ & $\begin{array}{c}1.583 \\
\pm 0.1 \\
\end{array}$ & $\begin{array}{l}2.477 \\
\pm 0.2 \\
\end{array}$ & $\begin{array}{r}2.127 \\
\pm 0.1 \\
\end{array}$ & $\begin{array}{c}0.506 \\
\pm 0.1 \\
\end{array}$ & 0.279 \\
\hline & 3days & $\begin{array}{c}1.28 \pm \\
0.1 \\
\end{array}$ & $\begin{array}{l}2.517 \\
\pm 0.1 \\
\end{array}$ & $\begin{array}{l}4.737 \\
\pm 0.2 \\
\end{array}$ & $\begin{array}{l}0.000 \\
\pm 0.0 \\
\end{array}$ & $\begin{array}{c}0.840 \\
\pm 0.1 \\
\end{array}$ & 0.206 \\
\hline & 7days & $\begin{array}{l}1.567 \\
\pm 0.1 \\
\end{array}$ & $\begin{array}{l}2.167 \\
\pm 0.1 \\
\end{array}$ & $\begin{array}{c}9.330 \\
\pm 0.1 \\
\end{array}$ & $\begin{array}{l}0.000 \\
\pm 0.0 \\
\end{array}$ & $\begin{array}{c}1.503 \\
\pm 0.1 \\
\end{array}$ & 0.157 \\
\hline \multicolumn{2}{|c|}{ LSD } & 0.414 & 0.346 & 0.446 & 0.346 & 0.399 & \\
\hline \multirow{4}{*}{$\begin{array}{l}\text { Monacha } \\
\text { obstructa }\end{array}$} & Control & $\begin{array}{l}4.810 \\
\pm 0.3 \\
\end{array}$ & $\begin{array}{l}4.810 \\
\pm 0.3 \\
\end{array}$ & $\begin{array}{l}4.810 \\
\pm 0.3 \\
\end{array}$ & $\begin{array}{r}4.810 \\
\pm 0.3 \\
\end{array}$ & $\begin{array}{c}4.810 \\
\pm 0.3 \\
\end{array}$ & 0.018 \\
\hline & 1day & $\begin{array}{l}1.440 \\
\pm 0.2\end{array}$ & $\begin{array}{l}1.040 \\
\pm 0.5\end{array}$ & $\begin{array}{l}6.183 \\
\pm 0.2\end{array}$ & $\begin{array}{r}2.557 \\
\pm 0.1\end{array}$ & $\begin{array}{l}2.21 \\
\pm 0.1 \\
\end{array}$ & 0.245 \\
\hline & 3days & $\begin{array}{c}2.043 \\
\pm 0.1 \\
\end{array}$ & $\begin{array}{c}2.133 \\
\pm 0.1 \\
\end{array}$ & $\begin{array}{l}6.887 \\
\pm 0.2 \\
\end{array}$ & $\begin{array}{l}0.000 \\
\pm 0.0 \\
\end{array}$ & $\begin{array}{c}3.280 \\
\pm 0.1 \\
\end{array}$ & 0.168 \\
\hline & 7days & $\begin{array}{l}1.520 \\
\pm 0.1 \\
\end{array}$ & $\begin{array}{c}3.093 \\
\pm 0.1 \\
\end{array}$ & $\begin{array}{c}9.403 \\
\pm 0.2 \\
\end{array}$ & $\begin{array}{l}0.000 \\
\pm 0.0 \\
\end{array}$ & $\begin{array}{r}3.327 \\
\pm 0.3 \\
\end{array}$ & 0.214 \\
\hline \multicolumn{2}{|c|}{ LSD } & 0.389 & 0.334 & 0.477 & 0.346 & 0.419 & \\
\hline
\end{tabular}

$A=$ acetylsalicylic acid

$M=$ methomyl

$\mathrm{Ab}=$ abamectin 
Table 5. Effect of $\mathrm{LC}_{50}$ of methomyl, abamectin and their combination with acetylsalicylic acid ( $\mathrm{LC}_{25}$ of each) as contact on cholesterol $(\mathrm{mg} / \mathrm{dL})$ in two land snail species

\begin{tabular}{|c|c|c|c|c|c|c|c|}
\hline \multirow{2}{*}{$\begin{array}{c}\text { Snail } \\
\text { species }\end{array}$} & \multirow{2}{*}{$\begin{array}{c}\text { Periods } \\
\text { after } \\
\text { treatment }\end{array}$} & \multicolumn{5}{|c|}{ Cholesterol (mg/dL) } & \multirow[b]{2}{*}{ LSD } \\
\hline & & $\begin{array}{c}\text { Methomyl } \\
\text { (M) }\end{array}$ & $\begin{array}{c}\text { Abmectin } \\
(\mathrm{Ab})\end{array}$ & A-Acid & $M+A$ & $A b+A$ & \\
\hline \multirow{8}{*}{$\begin{array}{c}\text { Eobania } \\
\text { vermiculata }\end{array}$} & \multirow[t]{2}{*}{ Control } & 251.7 & 251.7 & 251.7 & 251.7 & & \multirow{2}{*}{0.018} \\
\hline & & & & & & \pm 1.7 & \\
\hline & \multirow{2}{*}{ 1day } & 211.5 & 206.5 & 323.2 & 234.4 & 210.7 & \multirow{2}{*}{3.326} \\
\hline & & \pm 1.3 & \pm 1.5 & \pm 3.0 & \pm 0.5 & \pm 0.5 & \\
\hline & \multirow{2}{*}{ 3days } & 204.4 & 201.5 & 443.0 & 0.000 & 205.5 & \multirow{2}{*}{3.859} \\
\hline & & \pm 1.6 & \pm 0.8 & \pm 4.0 & \pm 0.0 & \pm 0.6 & \\
\hline & \multirow{2}{*}{ 7days } & 207.1 & 204.3 & 475.2 & 0.000 & 207.5 & \multirow{2}{*}{12.13} \\
\hline & & \pm 0.1 & \pm 1.9 & \pm 1.0 & \pm 0.0 & \pm 0.5 & \\
\hline \multicolumn{2}{|c|}{ LSD } & 2.983 & 1.906 & 14.80 & 1.978 & 1.853 & \\
\hline \multirow{8}{*}{$\begin{array}{l}\text { Monacha } \\
\text { obstructa }\end{array}$} & \multirow{2}{*}{ Control } & 477.9 & 477.9 & 477.9 & 477.9 & 477.9 & \multirow{2}{*}{0.018} \\
\hline & & \pm 0.2 & \pm 0.2 & \pm 0.2 & \pm 0.2 & \pm 0.2 & \\
\hline & \multirow{2}{*}{ 1day } & 201.5 & 0.067 & 232.1 & 2.260 & 207.2 & \multirow{2}{*}{75.04} \\
\hline & & \pm 1.1 & \pm 0.3 & \pm 8.0 & \pm 1.1 & \pm 1.3 & \\
\hline & \multirow{2}{*}{ 3days } & 199.5 & 0.180 & 205.8 & 0.000 & 205.7 & \multirow{2}{*}{2.491} \\
\hline & & \pm 1.4 & \pm 0.5 & \pm 2.0 & \pm 0.0 & \pm 0.4 & \\
\hline & \multirow{2}{*}{ 7days } & 192.7 & 0.476 & 233.9 & 0.000 & 204.7 & \multirow{2}{*}{4.038} \\
\hline & & \pm 1.2 & \pm 0.9 & \pm 4.0 & \pm 0.0 & \pm 0.7 & \\
\hline \multicolumn{2}{|c|}{ LSD } & 13.06 & 0.063 & 95.03 & 0.141 & 13.21 & \\
\hline
\end{tabular}

A= acetylsalicylic acid

$M=$ methomyl

$A b=$ abamectin 
Table 6. Field performance of certain compounds against Eobania vermiculata.

\begin{tabular}{|c|c|c|c|c|}
\hline Treatment & $\begin{array}{c}\text { Rate of } \\
\text { application }\end{array}$ & $\begin{array}{c}\text { No. animals } \\
\text { before treatment }\end{array}$ & $\begin{array}{c}\text { No. alive animals } \\
\text { after treatment }\end{array}$ & $\begin{array}{c}\text { \% population } \\
\text { reduction }\end{array}$ \\
\hline Control & - & 35 & 18 & - \\
\hline Methomyl & $2.0 \mathrm{ml} / \mathrm{l}$ & 33 & 5 & 70.5 \\
\hline Abamectin & $3.0 \mathrm{ml} / \mathrm{l}$ & 40 & 8 & 86.0 \\
\hline Acetylsalicylic acid & $12.0 \mathrm{~g} / \mathrm{l}$ & 28 & 2 & 91.7 \\
\hline Methomyl + & & & 2 & 85.0 \\
\hline Acetylsalicylic acid & $1.0 \mathrm{ml} / \mathrm{l}+6.0 \mathrm{~g} / \mathrm{l}$ & 47 & 26 & 2 \\
\hline Abamectin + & & & & \\
\hline
\end{tabular}

Table 7. Field performance of certain compounds against Monacha obstructa.

\begin{tabular}{|c|c|c|c|c|}
\hline Treatment & $\begin{array}{c}\text { Rate of } \\
\text { application }\end{array}$ & $\begin{array}{c}\text { No. animals } \\
\text { before treatment }\end{array}$ & $\begin{array}{l}\text { No. alive animals } \\
\text { after treatment }\end{array}$ & $\begin{array}{c}\% \text { population } \\
\text { reduction }\end{array}$ \\
\hline Control & - & 100 & 79 & - \\
\hline Methomyl & $2.0 \mathrm{ml} / \mathrm{I}$ & 132 & 16 & 84.8 \\
\hline Abamectin & $2.0 \mathrm{ml} / \mathrm{l}$ & 114 & 44 & 51.3 \\
\hline Acetylsalicylic acid & $6.7 \mathrm{~g} / \mathrm{l}$ & 96 & 49 & 35.4 \\
\hline $\begin{array}{c}\text { Methomyl + } \\
\text { Acetylsalicylic acid }\end{array}$ & $1.0 \mathrm{ml} / \mathrm{l}+3.4 \mathrm{~g} / \mathrm{l}$ & 150 & 14 & 88.2 \\
\hline $\begin{array}{c}\text { Abamectin + } \\
\text { Acetylsalicylic acid }\end{array}$ & $1 . \mathrm{ml} / \mathrm{l}+3.4 \mathrm{~g} / \mathrm{l}$ & 90 & 28 & 60.6 \\
\hline
\end{tabular}




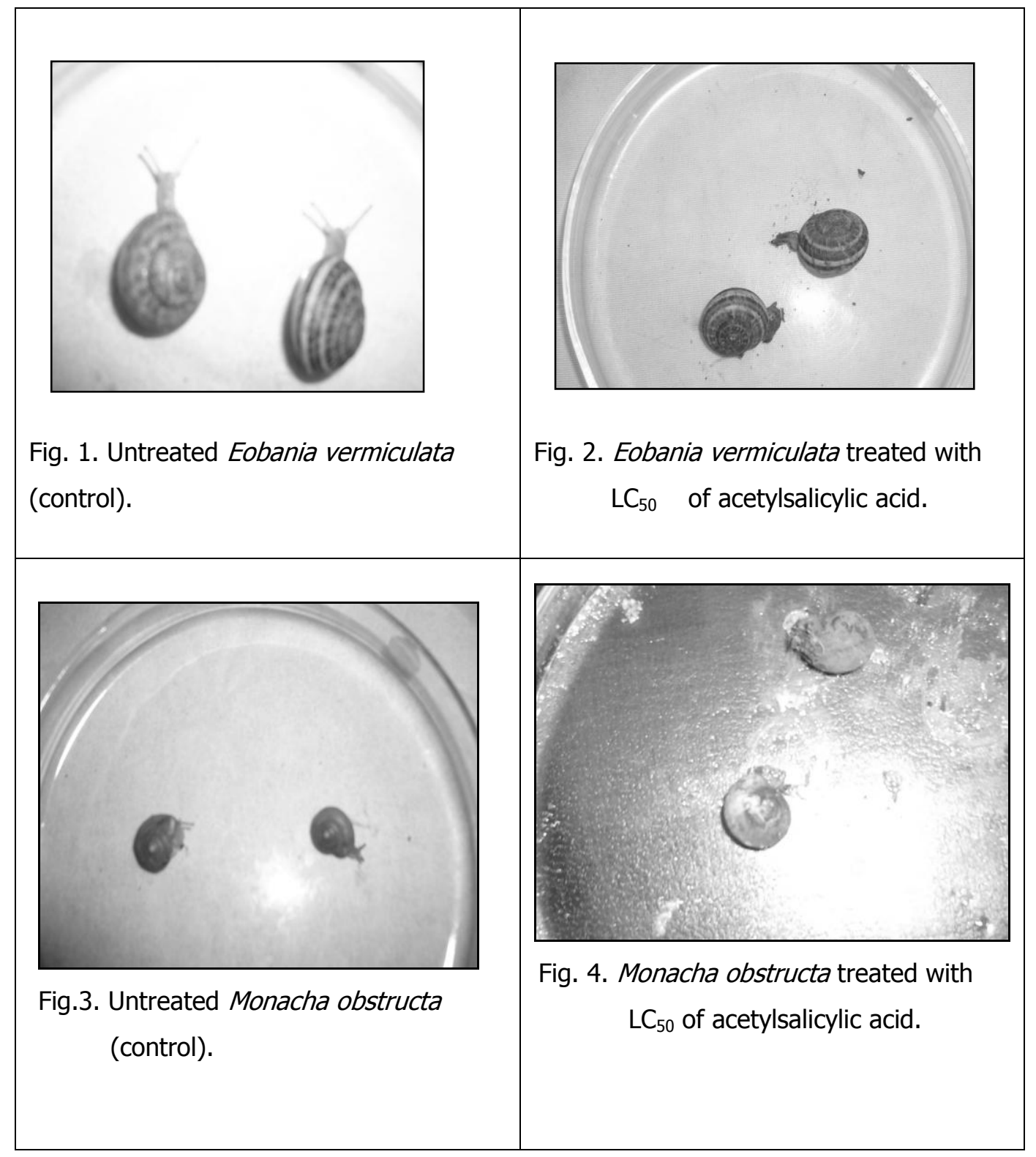




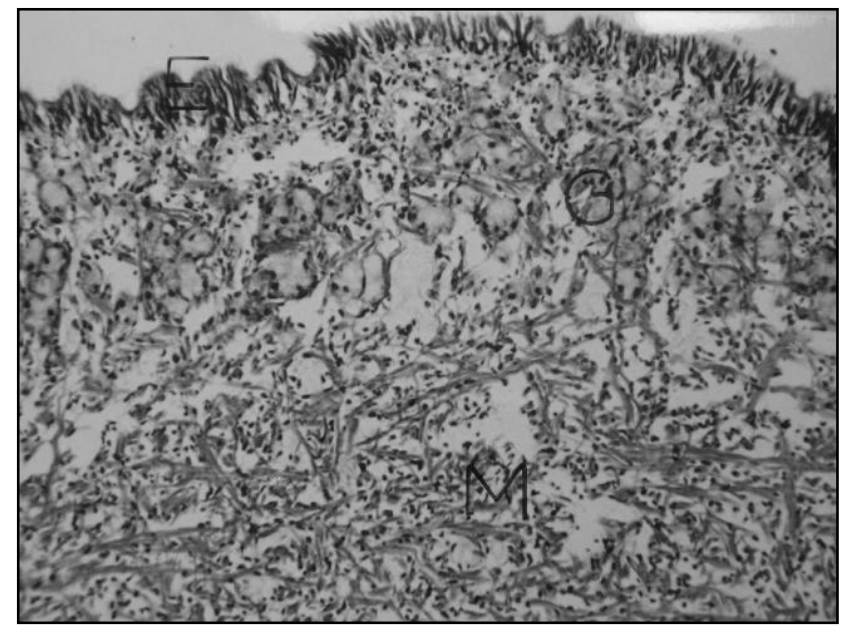

Fig. 5. Untreated Eobania vermiculata (control). Showing the normal histological structure of the covering pseudostratified layer $(E)$ and the underlying mucous gland $(G)$ in the muscular tissue $(M)$.

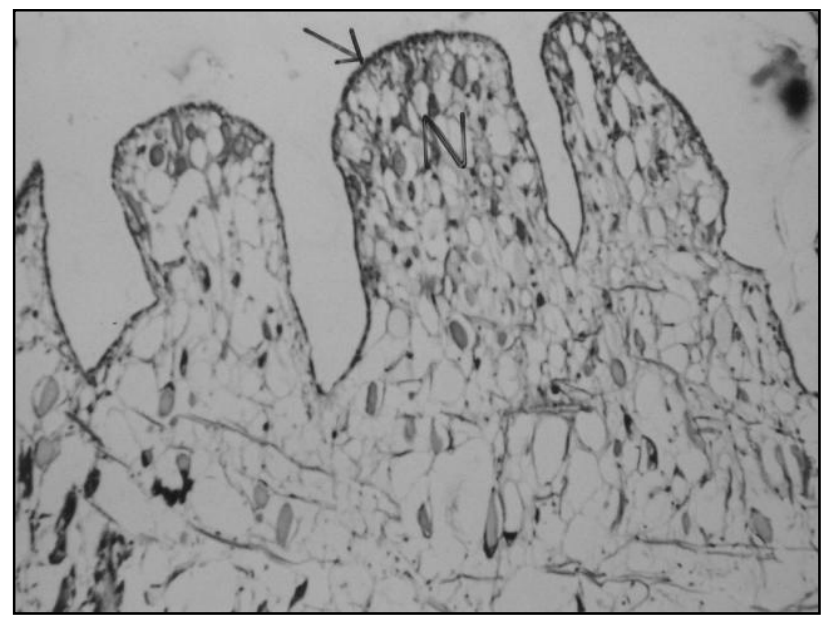

Fig. 6. Eobania vermiculata treated with acetylsalicylic acid showing diffuse necrosis of the covering epithelium and the underlying mucous glands as well as musculature. 


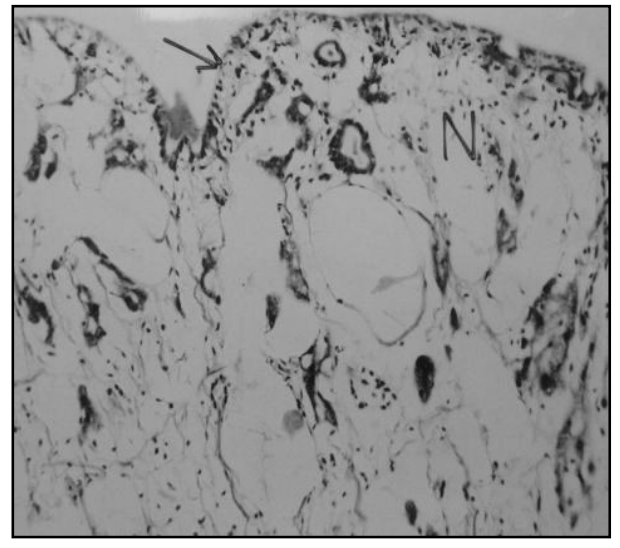

Fig.7. Eobania vermiculata treated with acetylsalicylic acid showing necrosis of the finger like projection fold and underlying musculature $(\mathrm{N})$.

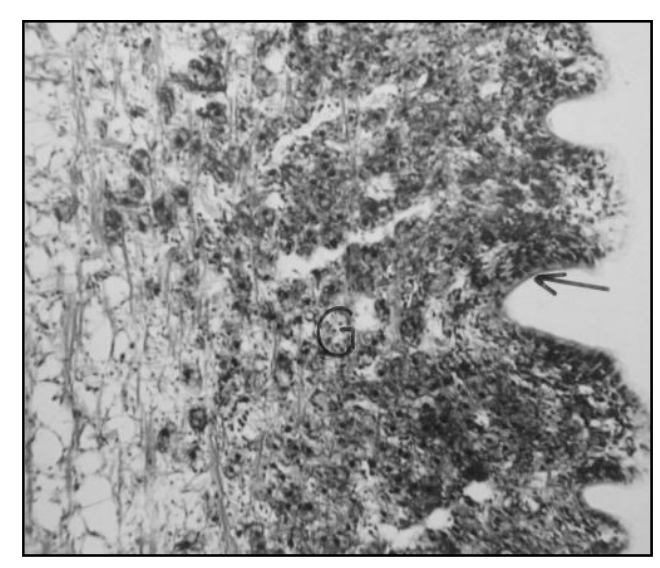

Fig.8. Untreated Monacha obstructa showing covering pseudostratified layer $(\mathrm{E})$ and the underlying the basophilic mucous glands $(\mathrm{G})$ in the muscular tissue (M).

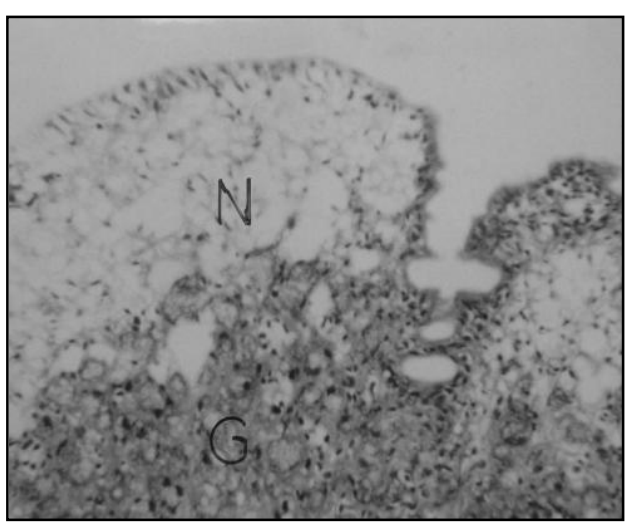

Fig.10. Monacha obstructa treated with acetylsalicylic acid showing necrosis of the covering epithelium and underlying mucous gland $(\mathrm{N})$. 


\section{REFERENCES}

1. Abdl-Kader Samah, M. 2001. Effects of Anagallis arvensis Extract as Molluscicide on Some Biological Aspects of Some Land Snails at Delta region. M. Sc. Thesis Faculty of Science, Zagazig University.101 pp., ARE.

2. Banchroft, J. D., Stevens, A. and Turner, D. R. 1996. Theory and practice of histological techniques. $4^{\text {th }}$ Ed. Churchil Livingstone, New York, London, Sanfrancisco, Tokyo.

3. Beltagi, S. M., El-Shennawy, M. S., Elkatan ,N. A. and Yousef, H. N. 2011. Physiological changes in the brown garden snail, Eobania vermiculata induced by sublethal doses of two botanical molluscicides. J. Egypt. Ger. Soc. Zool (63A): Comparative physiology, 375- 397.

4. Bergmeyer, H. 1963. Methods of enzymatic analysis. Academic press In New York, pp., 886.

5. Ellefson, R. D. and Caraway, W. T. 1976. Fundamentals of clinical chemistry . Ed. Titez NW, P 506.

6. Gabr, W. M. , Khidr Fatma, K. and Youssef, A. S. 2006-b. Effect of spinosad bioinsecticide as a bait and contact applications against three land snail species. Egypt J. Agric. Res., 84 (5): 1403- 1409.

7. Gabr, W. M., Youssef, A. S. and Khidr Fatma, K. 2006-a. Molluscicidal effect of certain compounds against two land snail species Monacha obstructa and Eobania vermiculata under laboratory and field conditions. Egypt J. Agric. Res., $84(1): 43-50$.

8. Henderson, C. and Tilton, W. F. 1952. Tests with acaricides against the brown wheat mite. J. Econ. Entomol., 18 (2): 157-161.

9. Henry, R. J. (1964). Clinical Chemistry, Principles and Techniques. Harper and Row Publishers. New York P. 181.

10. Kandil, M. A., El-Deeb, H.I., Eweis, E.A., Mobarak Soha, A. 2007. Molluscicidal activity of binary mixtures of some pesticides with acetylsalicylic or tannic acids against the land snails Eobania vermiculata and Monacha obstructa. J. Egypt Ger. Soc. Zool., (53D): Invertebrate zoology and parasitology: 77- 87.

11. Khater, A. A., A. A. El-Sheakh, M. K. El-Sheamy and M. Z. Hussein. 1990. Biochemical effects of lannate and larvin on Tilapia nilotica fingerlings. Egypt. J. Appl. Sci., 5(8): 227-235.

12. Kind, P. R. N. and King, E. J. 1954. Estimation of plasma phosphatase by determination of hydrolysed phenol with amino antipyrine. J. Clin. Path., 7: 322326. 
13. Kumari, P. G., Doss, P. J., Ramani, K. S. A., Vijaya, P. and Rao, M. R. 1999. Studies on some tissue lipid metabolic profiles of the snail Pila globosa (Swainson) under phenthoate toxic stress. J. of Econ. Physiology., 2 (1): 25-30.

14. Miller, E., Swails, S., Swails, D., Oslon F. and Stalen R. T. 1988. White garden snail Theba pisana efficacy of selected bait and sprayable molluscicides. J. Agric. Entomol., 5 (3): $189-197$.

15. Mitobe, Y., Hiraishi, H., Sasai, T.: Shimada, T. and Terano, A. 2000. The effects of Asprin on antioxidant defences cultured rat gastric mucosal cells. Aliment pharmacol. Ther., 14 (1): 10-17.

16. Price, J. F. 1984. Field evaluation of new pesticides for control of leafminers, mites and aphids on Flower Crops. Proceeding, Florida State Horticulture Society, 96: 278- 291.

17. Rao, I. G., Singh Amrita, Singh, V. K., and Singh, D. K. 2003. Effect of single and binary combinations of plant derived molluscicides on different enzyme activities in the nervous tissue of Achatina fulica. J. of Applied. Toxicology., 23 (1): 19- 22.

18. Saxena, P. K., Singh V. P., Kondal J. K. and Soni G. L. 1989. Effect of some pesticides on in vitro lipid and protein synthesis by the liver of the freshwater teleost, Channa punctatus (BL.). Environ. Pollut., 58: 273-276.

19. Wang, G. Z., Huang, G. P. , Yin, G. L., Zhou, G., Guo, C. J., Xie, C. G., Jia, B. B. and Wang, J. F. 2007. Asprin can elicit recurrence of gastric ulecer induced with acetic acid in rats. Cell physiol. Biochem., 20 (1-4): 205- 212.

20. Zollner, N. and Kirsch, K. 1962. Determination of Lipids (micro method) by means of sulphophosphovanilin reaction common to many natural lipids (allknown plasma lipids) Z. Gas Exp. Med., 135: 545-561. 


\title{
تأثير حمض الاستايل ساليسليك على النشاط الفسيولوجى للغذة المخاطية فى القواقع الارضية
}

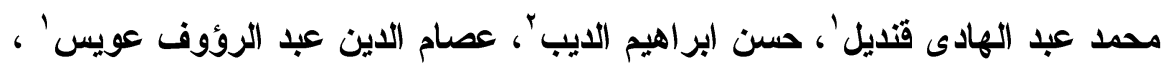

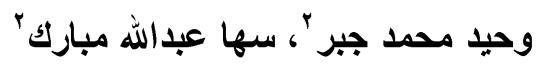

$$
\text { r r . . كلبة الزراعة- جامعة القاهرة. بحوث وقاية النباتات- مركز البحوث الزراعبة. }
$$

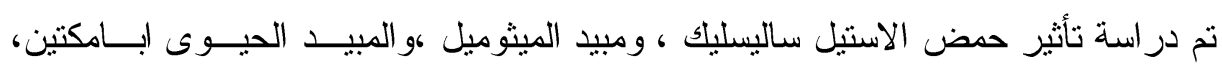
وخليط كلا من المبيدين مع حمض الاستيل ساليسليك على بعض العو امل البيوكيميائية (الكالين و اسيد

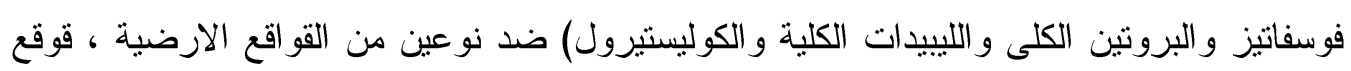

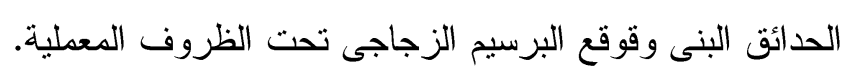

عوملت القو اقع بالتركيز المميت للنصف (LC50) لكل مبيد وكذللك الخليط بطريقة الملادسة.

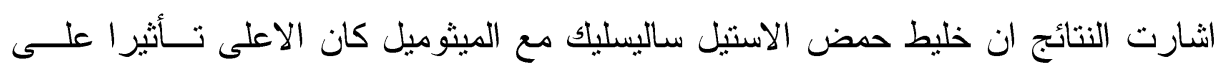

$$
\text { جميع العو امل البيوكيميائية التى تم تقدير ها فى كلا النوعين من القو اقع. }
$$

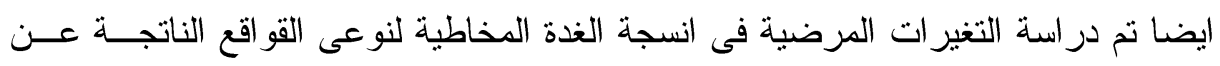

$$
\text { المعاملة بحمض الاستيل ساليسليك. }
$$

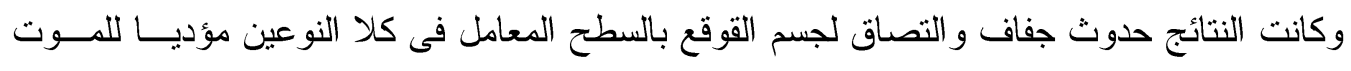

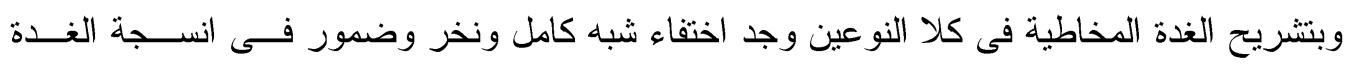

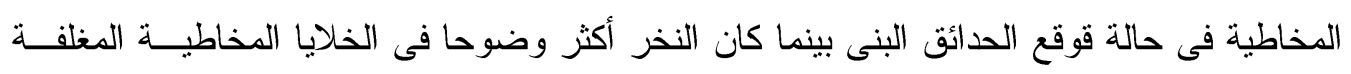
للغدة المخاطية فى حالة قوقع البرسيم الزجاجى.

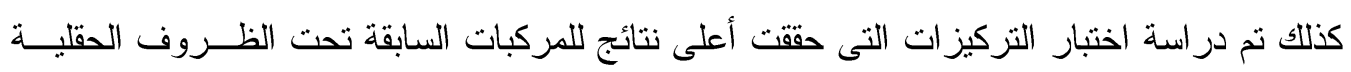

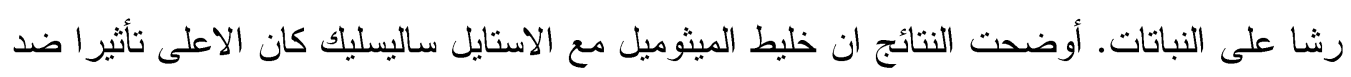
نوعى القو اقع كما فى النتائج المعملية. 